Article

\title{
Crop Litter Has a Strong Effect on Soil Organic Matter Sequestration in Semi-Arid Environments
}

\author{
Nikolaos V. Paranychianakis ${ }^{1, *}$, Giorgos Giannakis ${ }^{1}{ }^{(D}$, Daniel Moraetis ${ }^{2}{ }^{(D}$, Vasileios A. Tzanakakis ${ }^{3}$ \\ and Nikolaos P. Nikolaidis ${ }^{1}$ \\ 1 School of Environmental Engineering, Technical University of Crete, 73100 Chania, Greece; \\ geogiann@gmail.com (G.G.); nikolaos.nikolaidis@enveng.tuc.gr (N.P.N.) \\ 2 Department of Applied Physics and Astronomy, University of Sharjah, \\ Sharjah P.O. Box 27272, United Arab Emirates; moraetis@yahoo.gr \\ 3 Department of Agriculture, School of Agricultural Science, Hellenic Mediterranean University, \\ 71410 Iraklion, Greece; vtzanakakis@hmu.gr \\ * Correspondence: niko.paranychianakis@enveng.tuc.gr
}

Citation: Paranychianakis, N.V.; Giannakis, G.; Moraetis, D.;

Tzanakakis, V.A.; Nikolaidis, N.P. Crop Litter Has a Strong Effect on Soil Organic Matter Sequestration in Semi-Arid Environments.

Sustainability 2021, 13, 13278. https:/ / doi.org/10.3390/su132313278

Academic Editor: Rajan Ghimire

Received: 3 October 2021

Accepted: 26 November 2021

Published: 30 November 2021

Publisher's Note: MDPI stays neutral with regard to jurisdictional claims in published maps and institutional affiliations.

Copyright: (c) 2021 by the authors. Licensee MDPI, Basel, Switzerland. This article is an open access article distributed under the terms and conditions of the Creative Commons Attribution (CC BY) license (https:/ / creativecommons.org/licenses/by/ $4.0 /)$.

\begin{abstract}
The agricultural soils in the Mediterranean are characterized by low stocks of soil organic matter (SOM) because of the intensive management practices and constraints on litter inputs to the soil imposed by environmental conditions (low precipitation, high evapotranspiration). To date, several studies have provided evidence for a low potential of Mediterranean agroecosystems, especially on its southern part, to store C, even under soil conservation practices (e.g., non-tillage), questioning the capacity of commonly applied practices to restore soil health, mitigate climate change and improve resilience of agroecosystems to climate extremes. Using paired orchards of avocado and olive trees, we show that soils in the South Mediterranean have a high potential for C storage that depends strongly on crop type and soil properties. Soils planted with avocado trees showed higher SOM contents compared to olive trees mainly in the upper soil layer $(0-10 \mathrm{~cm})$ which were linked to higher inputs and litter chemistry. Our findings enable us to re-define achievable thresholds of SOC $(\approx 8 \%)$ in Southern Mediterranean soils to store $C$, to quantify the effect of different cropping systems, and the period required to reach this potential and how this potential is affected by soil properties. Thus, the findings have profound implications for the design of soil conservation practices compatible with Mediterranean conditions and developing initiatives describing achievable targets of SOM restoration depending on soil properties and cropping systems.
\end{abstract}

Keywords: carbon sequestration; avocado; olive trees; SOC; decomposition rate; respiration rate

\section{Introduction}

Soil organic matter (SOM) is a strong determinant of soil health status [1], and there has been a growing concern in recent years for the development of effective soil health restoration practices to improve soil productivity, increase crop yield, and enhance the resilience of agroecosystems to climate change [2,3]. Additionally, increasing $C$ sequestration to the soil can also contribute to the mitigation of global warming [4].

Despite recent breakthroughs in the mechanisms regulating SOM formation and loss [5-10], our understanding on the controls of SOM in agroecosystems remains incomplete. Climate, soil properties, cropping systems, and agronomical practices and their interactive effects are recognized as important controls of SOM dynamics [11-15].

Crops may affect SOC stocks through litter quantity and chemistry $[16,17]$, which in turn may affect decomposing microbial communities (Yan et al., 2021) and their carbon use efficiency [18]; hence, SOM formation [16,19]. The current paradigm of SOM formation is that microbially-processed plant-derived organic-C is preferentially associated with mineral surfaces to form SOM [8,9]. Complimentarily, plant metabolites can also be directly absorbed on mineral surfaces [20]. Overall, high-quality litters (easily decomposable) have 
a greater contribution in SOM formation [21] compared to litters with a high proportion of aromatic compounds (e.g., lignin), but notable deviations have been also reported [19,22]. Although some studies have provided support for the strong effect of litter composition on SOM formation and accumulation [23-25], a better understanding of litter's effect on SOM is needed to design best management practices for agroecosystems, to improve the capacity of existing tools $[21,26]$, and to provide more accurate predictions for the different cropping systems and environmental conditions.

In (semi-)arid environments, low precipitation and high evapotranspiration rates constrain primary productivity [15] and stimulate high turnover rates of SOM, which could outweigh the influence of other controls, such as soil properties or differences in litter inputs and chemistry among cropping systems. This assumption is supported by surveys on SOM variation in semi-arid Mediterranean landscapes revealing low SOM content across sites, despite the differences in soil properties, cropping systems, and applied agronomical practices [27]. In line with this, model simulations confirm the slow accumulation rate of SOM in Mediterranean soils, which takes up to several decades to restore soil quality [28]. For example, estimated rates of $\mathrm{C}$ accumulation in non-tilled fields to $0.34 \mathrm{t} \mathrm{C} / \mathrm{ha} \mathrm{yr}$ for the first 20 years and less than $0.10 \mathrm{t} \mathrm{C/ha} \mathrm{yr} \mathrm{afterwards} \mathrm{[28],} \mathrm{that} \mathrm{are} \mathrm{substantially}$ lower than the average accumulation rates of the " 4 per 1000" initiative. This evidence underlines the need for a better understanding of the controls of SOM in such environments to set realistic thresholds of SOM restoration, apply effective agronomical practices, and promote new cropping systems that can contribute to the development of sustainable agroecosystems. Although several works have estimated the effect of litter input on SOM dynamics, it remains unclear whether differences in litter chemistry among crops could reverse, or at least mediate, the climate-imposed constraints in SOM sequestration in (semi)-arid environments.

To improve our understanding on the controls of SOM sequestration in Mediterranean agroecosystems, we performed a field survey at Koiliaris Critical Zone Observatory (CZO), a typical Mediterranean watershed with severely degraded soils [29]. We investigated the effect of crop type on SOM sequestration at fields planted with olive trees, the dominant crop in the South Mediterranean, and in avocado orchards, an increasingly adopted crop in the Mediterranean. The main objectives of this work were to investigate: (i) whether the crop type influences SOM sequestration potential in agroecosystems and to quantify its effect size, (ii) to quantify the control of soil properties in SOM sequestration dynamics, and (iii) to translate these findings to achievable thresholds of SOM restoration in the Mediterranean agroecosystems.

\section{Materials and Methods}

\subsection{Site Description}

The selected sampling sites (1 to 5) are located at the central part of the Koiliaris Critical Zone Observatory (CZO) (005-12-489E, 039-22-112N) Chania, Crete, Greece (Supplementary Figure S1). The study area has a semi-arid climate with a mean annual precipitation of $654 \mathrm{~mm}$ and temperature of $17.3^{\circ} \mathrm{C}$. The soils in the Koiliaris CZO have been severely degraded by the intensive agricultural practices and overgrazing [29] and have been depleted in SOM [27]. In each sampling site, two paired fields, one planted with avocado, and one planted with olive trees of the same age, were selected to capture the variability of SOM in the soil of different cropping systems at the Koiliaris CZO. The proximity of fields minimized the variation of soil properties and allowed for the accurate estimation of the influence of crop type on $C$ sequestration. The agronomical management practices at the studied sites are summarized in Table 1. 
Table 1. Description of sites and the individual fields with regard to the management practices.

\begin{tabular}{ccr}
\hline Site & Field & Description \\
\hline Site 1 & Avocado & A 30-year old plantation; not-tilled in the last decade; commercial fertilizer \\
\hline & Olive & A 25-year old orchard; tilled; commercial fertilizer \\
\hline Site 2 & Avocado & A 20-year old plantation; yearly tilled; commercial fertilizer \\
\hline & Olive & A 20-year old orchard; yearly tilled; commercial fertilizer \\
\hline Site 3 & Avocado & A 18-year old plantation; yearly tilled; commercial fertilizer \\
\hline Site 4 & Ovocado & A 20-year old orchard; yearly tilled; commercial fertilizer \\
\hline & Olive & A 8-year old plantation; yearly tilled; commercial fertilizer \\
\hline Site 5 & Avocado & A 30-year old plantation; tilled in the last decade; commercial fertilizer \\
\hline & Olive & A 30-year old orchard; non-tilled; not fertilized
\end{tabular}

The average application of $\mathrm{N}$ is approximately $10 \mathrm{~kg} / \mathrm{ha}$. Fields before the crops were cultivated with cereals except in Site 4 that was planted with olive trees.

\subsection{Field Samplings, Chemical and Mineralogical Analyses}

Soil samples (three to six soil cores from each field) were taken from 0 to 10 and 11 to $20 \mathrm{~cm}$ soil depths in September 2018 from the five paired fields (avocado trees and olive trees). Samples were passed through a $2 \mathrm{~mm}$ mesh immediately after sampling at the field and maintained on ice packs at $4{ }^{\circ} \mathrm{C}$ until they were transferred to the laboratory for chemical and physical analyses.

Particle size analysis was carried out by the Bouyoucos hydrometer method in two samples [30] per field (four samples per site) at the $0-10 \mathrm{~cm}$ soil depth. The soil bulk density (BD) was determined by sampling two undisturbed soil cores per field of a known volume and drying them at $105^{\circ} \mathrm{C}$ to constant weight. The soil organic carbon (SOC) and total (TN) contents were measured in an elemental analyzer (Analytik Jena Multi N/C 2100S) after homogenizing and grinding the samples to a fine powder. Niton XL3t Goldd (Thermo Fischer, Waltham, MA, USA) X-ray fluorescence (XRF) analyses were performed in two soil samples per field at the $0-10 \mathrm{~cm}$ soil depth.

\subsection{Respiration}

Soil $\mathrm{CO}_{2}$ fluxes were assessed in spring (18 April), summer (12 July) and autumn (26 September) of 2019 using a closed soil respiration system (LI-COR 6400 LI-COR Inc., Lincoln NE, Dearborn, MI, USA) connected to a LI-6400 09 soil chamber. The soil chamber was used with collars inserted $2.5 \mathrm{~cm}$ in the soil. Four to six measurements were performed randomly in each field per sampling date.

\subsection{Litter Decomposition Rate}

To estimate differences in litter decomposition rates between crops, we used a modification of the protocol developed by [31]. Specifically, tea bags were filled with leaves from olive and avocado trees and were treated according to the above protocol. Mature leaves were collected from several trees, and they crashed into small pieces before they used to fill in the tea bags. Briefly, litter bags were buried in the soil containers at a depth of approximately $3 \mathrm{~cm}$, maintained at $60 \%$ water holding capacity and incubated at a constant temperature of $25^{\circ} \mathrm{C}$. Three bags were removed at each time interval per litter type to estimate decomposition rates. An exponential decay function was fitted to the data to estimate decomposition rate constant $\mathrm{k}$ [31] of the labile fraction of the litter. The recalcitrant fraction of litter is assumed to remain constant during the short incubation period (95 days in this case) [31]. The temperature tested allowed us to draw robust conclusions, whether the labile fraction of litter has been decomposed. To fit the exponential decay function, we used the "nls" function of the R-core assuming an asymptote at the late stage of incubation period fit $<$ nls $(Y \sim \operatorname{SSasymp}(X$, Asym, R0, lrc $)$, data $=$ data $)$. 


\subsection{Statistical Analyses}

A mixed-effects model was used for the analysis of variance (ANOVA) with the site as a random effect. More specifically, the following general model, Model Site + Crop + Depth + Site:Crop:Depth, was used and implemented in the "lme4" package in the R environment while the "emmeans" package was used for the pairwise comparisons of the treatments. In the case of respiration rate, bulk chemical analysis and soil properties, the "soil depth" term was not applicable. The assumptions of linearity and normality and the homogeneity of variance in the residuals were tested with the diagnostic plots. Correlations were performed with the Pearson method with the "ggpubr" package. All statistical analyses were performed in the R statistical platform.

\section{Results}

\subsection{Soil Physico-Chemical Properties}

Sampling Sites (1 to 5) showed strong differences in their physico-chemical properties $(p<0.01)$. Based on soil texture, soils in Sites 1 and 5 are classified as Clayey, and in Sites 2, 3, 4 as Clay loamy (Table 2). Soil texture analysis confirmed the affinity between the paired fields (avocado vs olive trees) except in Site 1, where the avocado field had slightly greater clay content (Table 2). Regarding the soil bulk density, a significant effect of crop was found in Sites 1, 2 and 5 in accordance with the higher difference in SOM content between cropping systems (Table 2). Soil pH was circum-neutral and only that of Site 5 differed significantly from the other sampling sites $(p<0.05)$. The bulk chemical analysis also revealed significant differences between sites $(p<0.05)$. Soils in Site 4 had the highest content of $\mathrm{Al}_{2} \mathrm{O}_{3}$ and soils in Site 5 the lowest (Table 3). Soils in Site 5 also had the lowest contents of $\mathrm{SiO}_{2}$, while the highest content of $\mathrm{SiO}_{2}$ was found in Sites 1, 2 and 3. A similar effect was observed for $\mathrm{Fe}_{3} \mathrm{O}$ content with soil in Site 1 having the highest content followed by soils in Sites 3, 2 and 4, while the lowest content was measured in Site 5. In contrast, the soil in Site 5 had the highest $\mathrm{CaO}$ content compared to the other sites (Table 3).

Table 2. Soil texture of the individual fields of the different sites (1 to 5) at the 0-10 soil depth.

\begin{tabular}{ccccccc}
\hline Site & Field & Clay (\%) & Silt (\%) & Sand (\%) & Classification & Bulk Density \\
\hline \multirow{2}{*}{ Site 1} & Avocado & $44.03(\mathrm{a})$ & $28.53(\mathrm{~b})$ & $27.44(\mathrm{c})$ & Clay & 1.09 \\
\cline { 2 - 6 } & Olives & $38.78(\mathrm{a})$ & $30.80(\mathrm{~b})$ & $30.49(\mathrm{c})$ & Clay Loam & 1.20 \\
\hline \multirow{2}{*}{ Site 2 } & Avocado & $28.83(\mathrm{c})$ & $33.28(\mathrm{~b})$ & $37.94(\mathrm{a})$ & Clay Loam & 1.14 \\
\cline { 2 - 7 } & Olives & $28.06(\mathrm{c})$ & $33.06(\mathrm{~b})$ & $38.88(\mathrm{a})$ & Clay Loam & 1.22 \\
\hline \multirow{2}{*}{ Site 3 } & Avocado & $32.26(\mathrm{~b})$ & $33.41(\mathrm{~b})$ & $34.34(\mathrm{~b})$ & Clay Loam & 1.21 \\
\cline { 2 - 6 } & Olives & $33.45(\mathrm{~b})$ & $30.92(\mathrm{~b})$ & $35.64(\mathrm{~b})$ & Clay Loam & 1.22 \\
\hline \multirow{2}{*}{ Site 4} & Avocado & $32.00(\mathrm{~b})$ & $33.69(\mathrm{~b})$ & $34.34(\mathrm{~b})$ & Clay Loam & 1.28 \\
\cline { 2 - 6 } & Olives & $32.66(\mathrm{~b})$ & $33.35(\mathrm{~b})$ & $34(\mathrm{~b})$ & Clay Loam & 1.33 \\
\hline \multirow{2}{*}{ Site 5 } & Avocado & $40.66(\mathrm{a})$ & $37.96(\mathrm{a})$ & $21.38(\mathrm{~d})$ & Clay & 1.24 \\
\cline { 2 - 6 } & Olives & $42.23(\mathrm{a})$ & $38.09(\mathrm{a})$ & $19.68(\mathrm{~d})$ & Clay & 1.11 \\
\hline
\end{tabular}

Different letters in parentheses denote statistically significant differences among sites.

Overall, SOC content followed the general trend of clay content with the highest values measured in Sites 1 and 5 and the lowest in Site 3 (Figure 1A), but regression analysis revealed a significant relationship only for olive crops providing support that additional affected SOC sequestration (Supplementary Figure S2). The lowest SOC content was found in the youngest avocado plantation in Site 4. Within sampling sites, fields planted with avocado trees had greater content of SOC compared to olive tree fields $(p<0.001)$. This effect, however, was strongly mediated by site (Figure 1A). SOC content was also significantly affected by soil depth $(p<0.001)$ with the greatest contents measured in the $0-10 \mathrm{~cm}$ range (Figure 1A). When interpreted against data from earlier studies from agricultural fields and sites with natural vegetation (shrubs and forests), SOC content 
of avocado fields was overly higher at the upper soil layer, but these differences nearly disappeared at the 10-20 cm soil depth (Figure 1A).

Table 3. Soil bulk chemical analysis and $\mathrm{pH}$ of the individual fields at the different Sites (1 to 5) at the $0-10$ soil depth.

\begin{tabular}{|c|c|c|c|c|c|c|c|c|}
\hline Site & Field & $\begin{array}{c}\mathrm{MgO} \\
(\%)\end{array}$ & $\begin{array}{c}\mathrm{Al}_{2} \mathrm{O}_{3} \\
(\%)\end{array}$ & $\begin{array}{c}\mathrm{SiO}_{2} \\
(\%)\end{array}$ & $\begin{array}{c}\mathrm{K}_{2} \mathrm{O} \\
(\%)\end{array}$ & $\begin{array}{c}\mathrm{CaO} \\
(\%)\end{array}$ & $\begin{array}{c}\mathrm{Fe}_{2} \mathrm{O}_{3} \\
(\%)\end{array}$ & $\mathrm{pH}$ \\
\hline \multirow{2}{*}{ Site 1} & Avocado & $<0.1$ & 7.9 (a) & $60.4(b)$ & 1.6 & $3.4(b)$ & $7.8(\mathrm{a})$ & $7.16(b)$ \\
\hline & Olives & $<0.1$ & 7.6 (a) & $57.3(b)$ & 1.5 & $3.8(b)$ & 7.1 (a) & $7.22(b)$ \\
\hline \multirow{2}{*}{ Site 2} & Avocado & $<0.1$ & 8.4 (a) & 79.7 (a) & 1.20 & 1.5 (c) & 4.5 (b) & $7.22(b)$ \\
\hline & Olives & 0.3 & 7.4 (a) & 68 (a) & 1.4 & $1.5(\mathrm{c})$ & $5.0(b)$ & $7.19(b)$ \\
\hline \multirow{2}{*}{ Site 3} & Avocado & $<0.1$ & $7.2(b)$ & 72.9 (a) & 1.7 & $1.4(\mathrm{c})$ & $5.1(b)$ & $7.21(\mathrm{~b})$ \\
\hline & Olives & $<0.1$ & $6.8(\mathrm{~b})$ & 72.8 (a) & 1.5 & $0.9(\mathrm{c})$ & $5.3(\mathrm{~b})$ & $7.20(b)$ \\
\hline \multirow{2}{*}{ Site 4} & Avocado & $<0.1$ & 5.7 (c) & 71.4 (a) & 1.7 & $1.4(\mathrm{c})$ & 4.2 (c) & $7.12(b)$ \\
\hline & Olives & $<0.1$ & $6.7(\mathrm{c})$ & 72.7 (a) & 1.5 & $1.3(\mathrm{c})$ & $4.6(\mathrm{c})$ & $7.14(b)$ \\
\hline \multirow{2}{*}{ Site 5} & Avocado & 0.3 & $4.3(\mathrm{~d})$ & $22.7(\mathrm{c})$ & 1.4 & 34.3 (a) & $3.2(\mathrm{~d})$ & $7.36(\mathrm{a})$ \\
\hline & Olives & $<0.1$ & $4.1(\mathrm{~d})$ & $22.5(\mathrm{c})$ & 1.5 & 35.2 (a) & $3.2(\mathrm{~d})$ & 7.43 (a) \\
\hline
\end{tabular}

Different letters in parentheses denote statistically significant differences among sites.

There was no consistent effect of crop on soil TN content (Figure 1B). For instance, in Sites 1 and 2, fields planted with avocado showed higher TN content compared to those planted with olive trees. An opposite effect, however, was observed in Site 3, Site 4, and Site 5 (Figure 1B). In line with the SOC, these differences were highest at the top-soil, while in the 10-20 cm soil depth these differences decreased (Site 1 and Site 5) or even disappeared (Site 2, Site 3, Site 4). When interpreted against findings from earlier studies from agricultural fields and sites with natural vegetation (shrubs), TN content of both crops was higher compared to findings from agricultural fields and natural vegetation at both soil depths (Figure 1B).

Differences between sites were also found in the $\mathrm{C} / \mathrm{N}$ ratio. Soils planted with avocado trees were characterized by greater $\mathrm{C} / \mathrm{N}$ ratios compared to soils planted with olive trees (Figure 1C). The estimated $\mathrm{C} / \mathrm{N}$ values were, however, substantially lower that those measured in earlier studies in the same watershed and likely were attributed to the lower TN contents measured in these samples (Figure 1C).

A significant relationship was established between SOC and TN content that was crop specific (Figure 2). This relationship was affected by soil depth with the relationships of SOC and TN of the different crops to tend to converge at the 10-20 cm soil depth (Figure 2). A further investigation of these relationships revealed that they were also site-specific (Supplementary Figure S3) that likely indicates a mediating effect of soil properties on these relationships.

\subsection{Soil Respiration and Litter Decomposition Rates}

Higher respiration rates were measured in fields planted with avocado compared to olive tree fields (Figure 3A). A seasonal effect was also observed that was more pronounced in fields planted with olive trees; in which a decrease in respiration rates was observed late in the season (September) (Figure 3B). To get further insights on the drivers that caused these divergent patterns of respiration, we interpreted the average SOC content in the $10 \mathrm{~cm}$ soil depth with respiration rate. A significant relationship was only set in fields planted with avocado (Figure 4A). Seasonal interpretation of the results revealed strong relationships between SOC and respiration rates in avocado fields in all the samplings and only in July for olive tree fields (Figure 4B). 

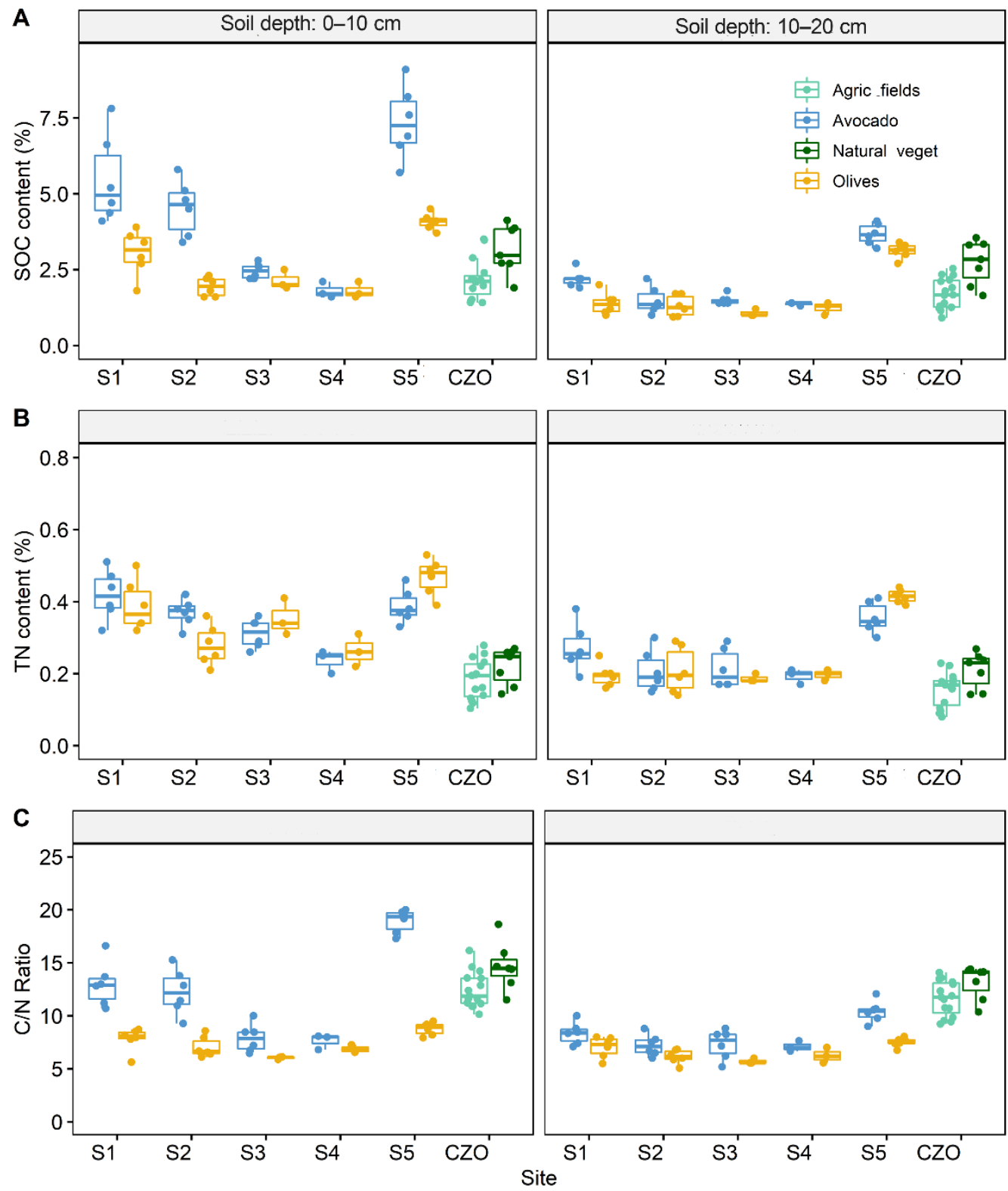

Figure 1. Effect of crop and soil depth on soil organic carbon (SOC) and total nitrogen (TN) content at different sampling Sites (1 to 5). (A) SOC content at the depth of 0-10 and 10-20 cm in Avocado and Olive tree orchards interpreted against averaged values from agricultural fields and sites with natural vegetation at the Koiliaris Critical Zone Observatory (CZO). (B) TN content at the depth of 0-10 and 10-20 cm in Avocado and Olive tree orchards interpreted against averaged values from agricultural fields and sites with natural vegetation from the Koiliaris CZO. (C) Corresponding values of the $\mathrm{C} / \mathrm{N}$ ratio. Averaged values of $\mathrm{SOC}, \mathrm{TN}$ and $\mathrm{C} / \mathrm{N}$ ratio were derived from [32]. The agricultural fields included olive orchards (11), citrus orchards (3) and cereals (1) while sites of natural vegetation included four sites with shrubs and three forest sites. 


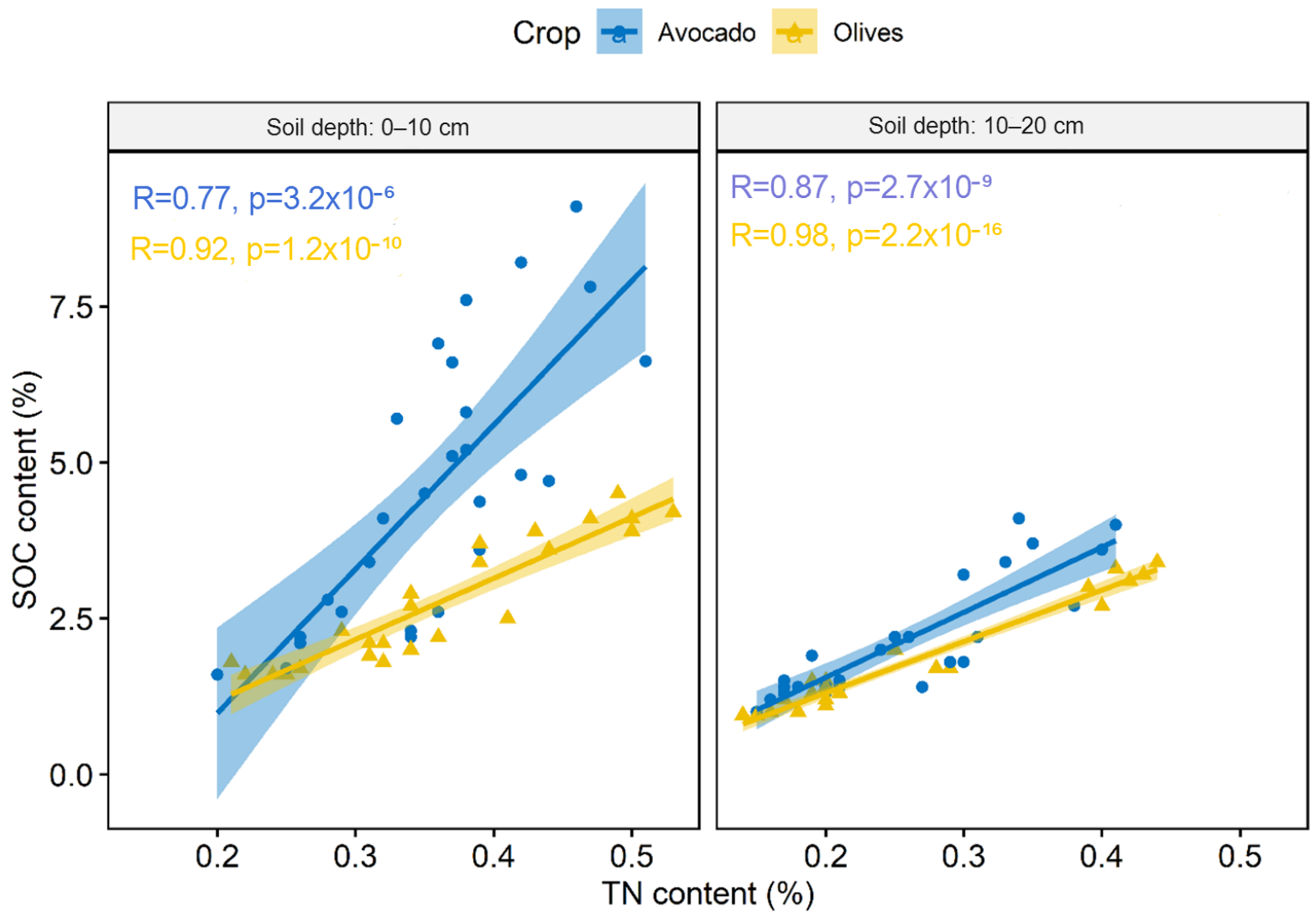

Figure 2. Correlation of the SOC and TN content in the different crops and soil depths.

A

Crop 审 Avocado

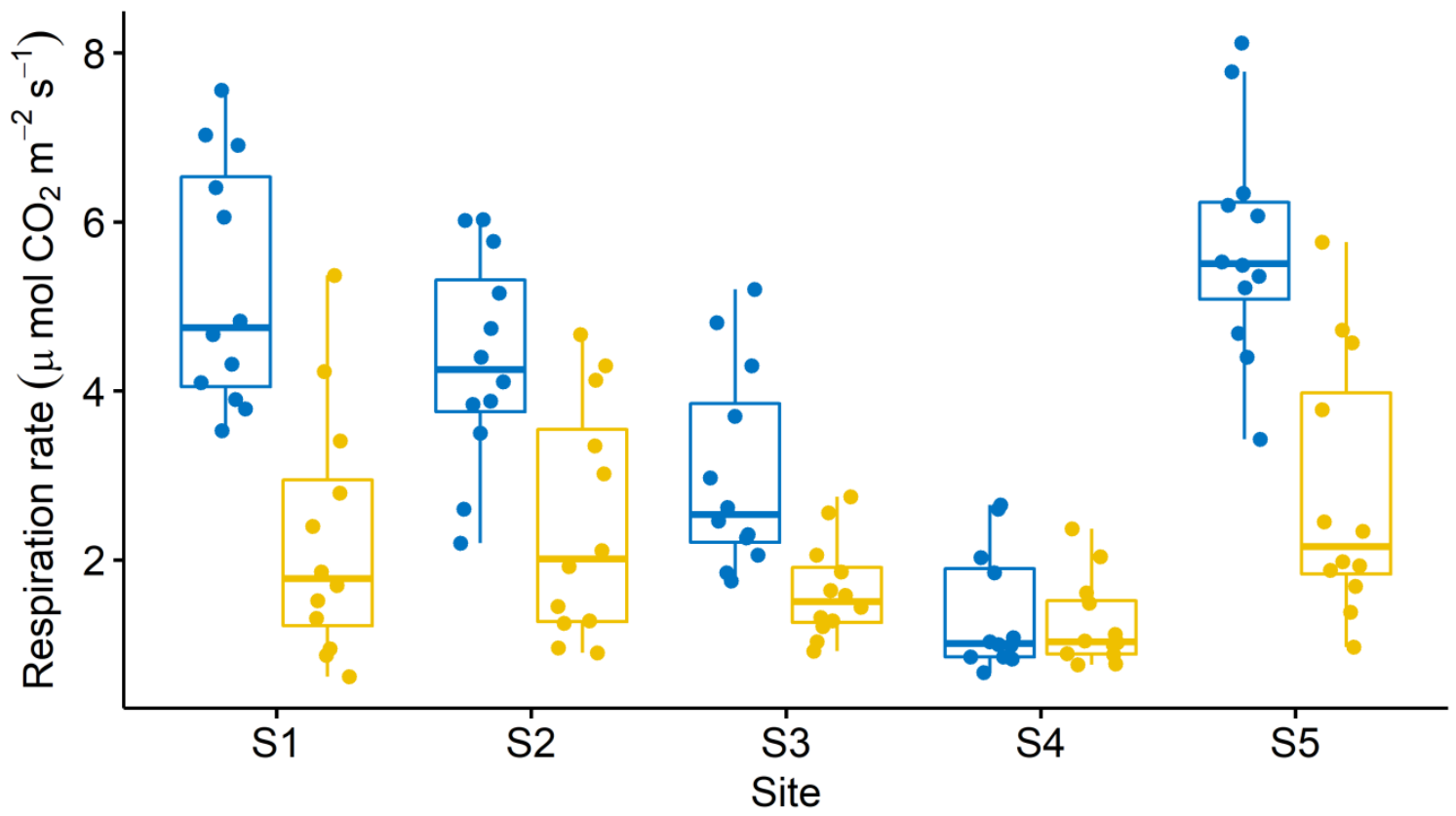

Figure 3. Cont. 


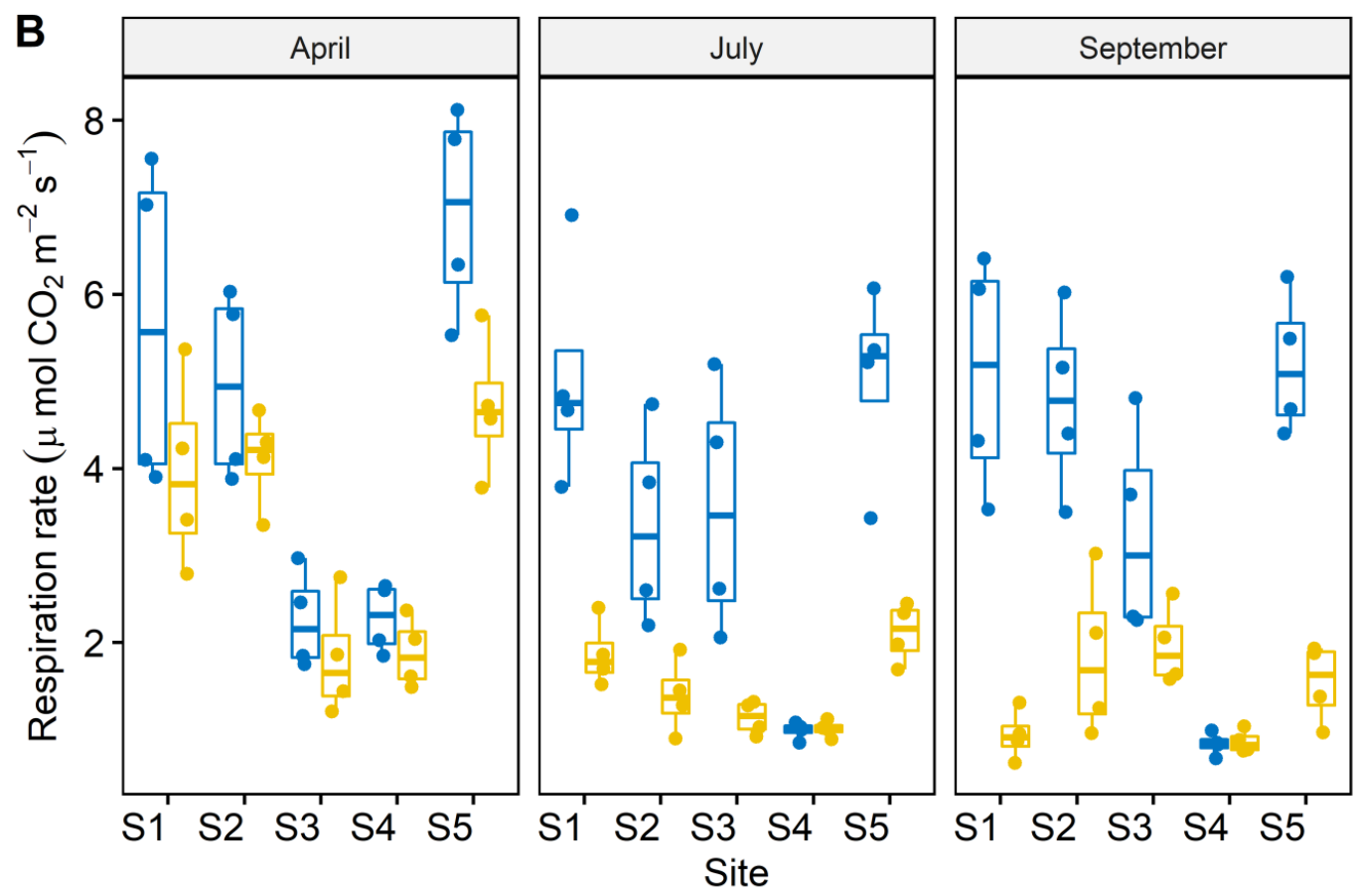

Figure 3. Soil respiration rate at the different sampling fields and crops: (A) cumulative and (B) at the individual sampling dates.
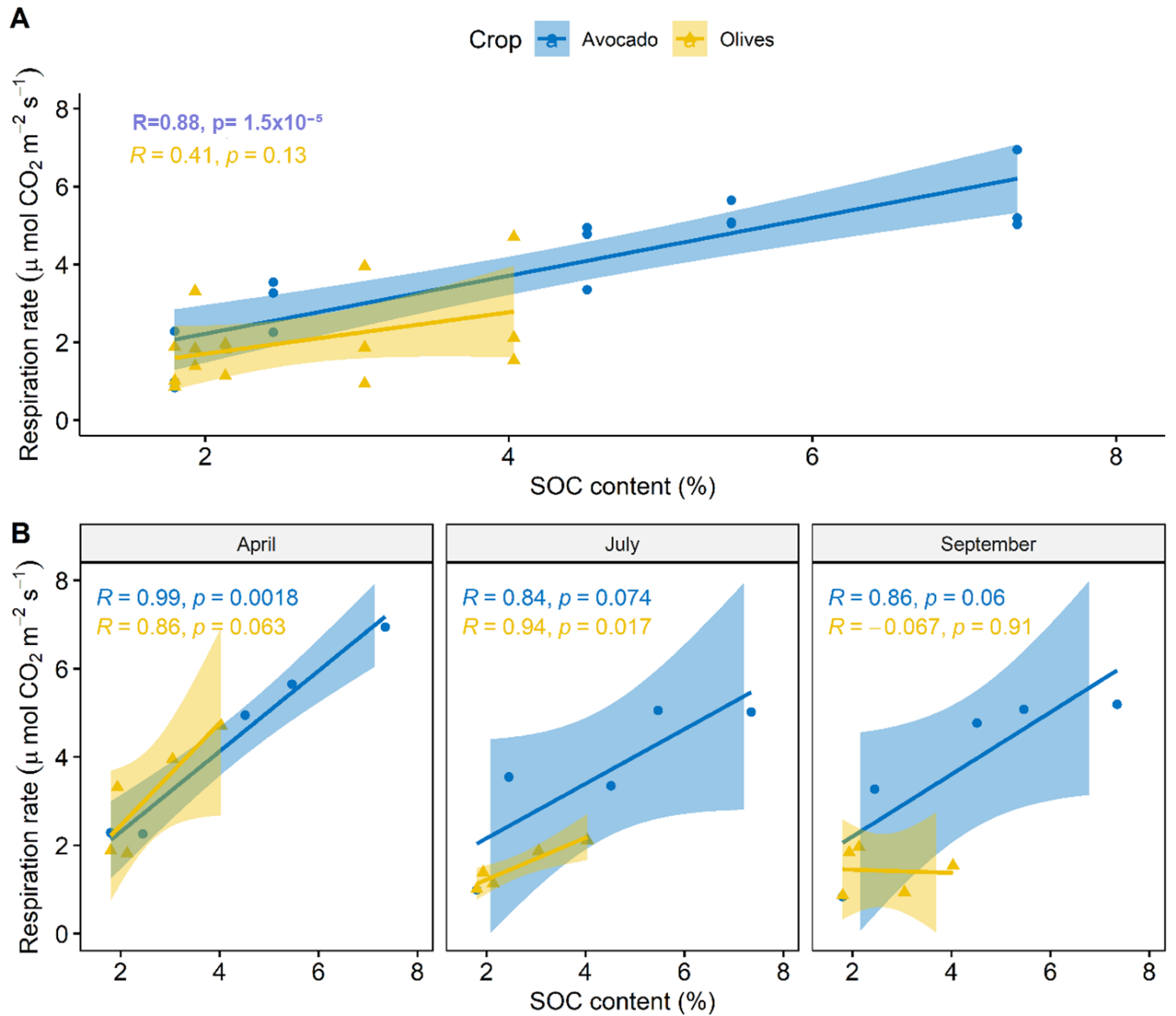

Figure 4. Correlation of soil respiration rate with SOC content at the $0-10 \mathrm{~cm}$ soil layer for the different crops. (A) Cummulative relationship for all samplings and (B) Relationships in the individual samplings. 


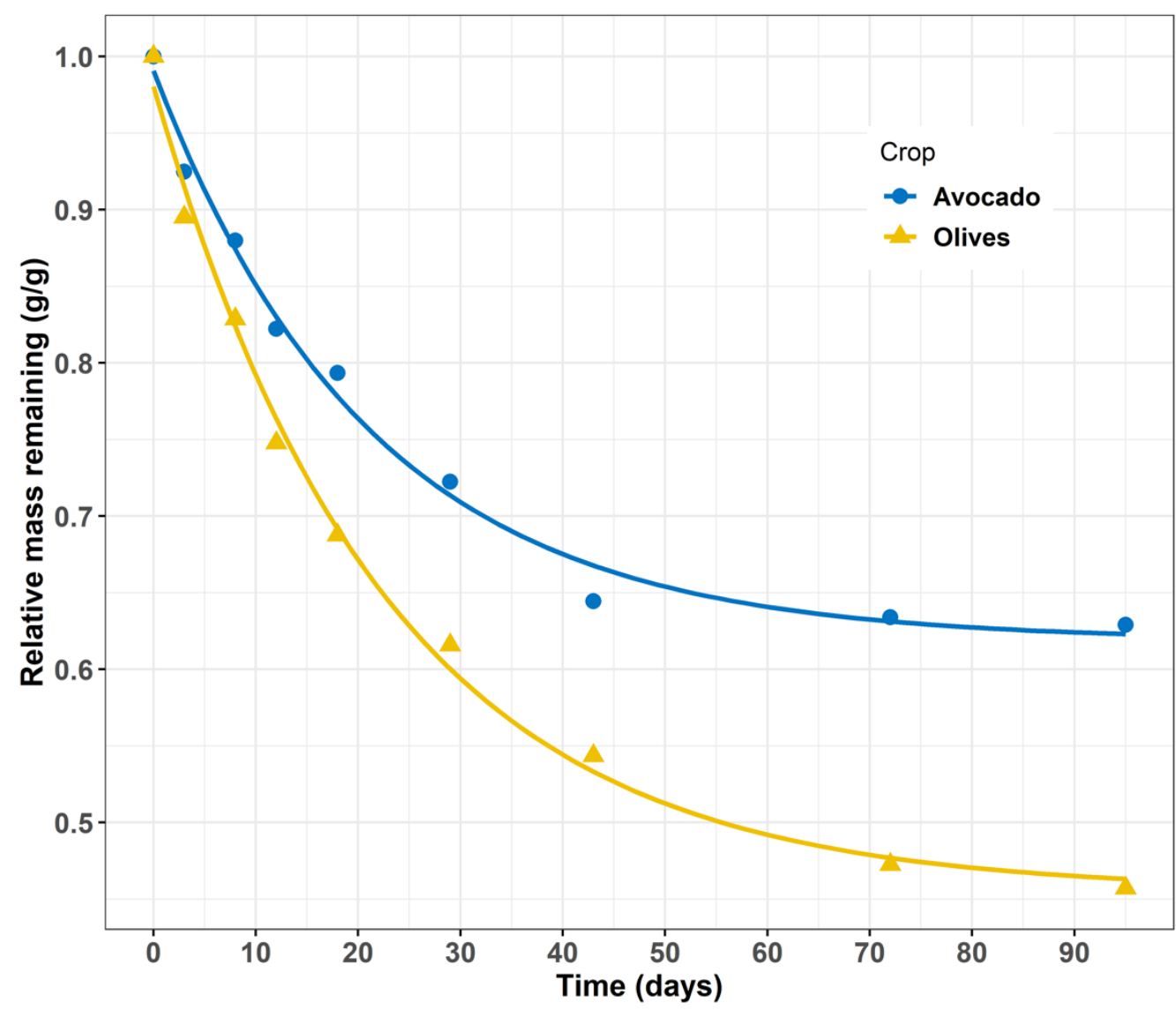

Figure 5. Decomposition rate of avocado and olive tree leaves at the $25{ }^{\circ} \mathrm{C}$ to estimate the labile fraction of crop litter. Lines correspond to an exponential decay function of the form $y=a e-k t+(1-a)$ with "a" the decomposable fraction of litter (0.381 and 0.545 for Avocado and Olive trees respectively) and " $k$ " the decomposition rate constant (-3.165 and -3.113 for Avocado and Olive trees respectively). Each point represents the average of three replicates.

\section{Discussion}

The Mediterranean region is a representative case of severely degraded soils $[29,33,34]$ and there is an urgent need to identify compatible agronomical practices for restoring soil health. Water deficits developed in such environments during the growing season constrain primary productivity of rain-fed (or sub-optimum irrigated) agroecosystems and, hence, litter inputs to the soils and SOM formation, a strong determinant of soil health [35]. Field studies and model simulations reveal a low potential for Mediterranean soils to accumulate SOM, even under well-tested soil restoration practices (e.g., non-tillage) [28,36,37]. For instance, simulations with the CAST model have revealed that long times are needed to reach defined SOM thresholds of soil quality improvement. High rates $\left(\approx 12 \mathrm{tC} \mathrm{ha}^{-1} \mathrm{yr}^{-1}\right)$ of organic amendment application were estimated for the successful restoration of SOM and soil structure in severely degraded soils and their maintenance $\left(7 \mathrm{tC} \mathrm{ha}^{-1} \mathrm{yr}^{-1}\right)$ [38] In line with this, increases in soil $\mathrm{C}$ stocks of olive orchards occurred only when the amount of organic inputs increased to $25 \mathrm{t} \mathrm{C} \mathrm{ha}^{-1} \mathrm{yr}^{-1}$, through the incorporation of mulched pruning's and seed residues [33].

Our findings update those of earlier studies $[28,33]$ and provide support that the potential of Mediterranean soils to sequester $\mathrm{C}$ is underestimated (Figure 1A). The cropspecific effect on soil $\mathrm{C}$ sequestration found in this work, particularly in the upper soil layer, supports the hypothesis that limitations imposed by climate and/or applied agronomic practices (e.g., residue burning) in the amount of litter inputs appear to constrain $C$ sequestration in Mediterranean soils. Avocado orchards are characterized by significantly 
higher litter inputs $(\approx 5.6 \mathrm{t} / \mathrm{ha})[39]$ compared to those of olive orchards $(\approx 1.6 \mathrm{t} / \mathrm{ha})$ [33]; however, at avocado orchards, litter inputs remained below those that have been estimated in a previous study for restoring or maintaining soil fertility [38], providing support that litter chemistry may have also stimulated the higher rates of $C$ sequestration in avocado fields. This assumption is consistent with earlier studies that have reported strong effects of litter chemistry on soil C sequestration $[22,25,40]$.

Surprisingly, SOM content in avocado fields exceeded that of sites with natural vegetation (shrubs and forests) which are commonly used to define upper thresholds of SOM restoration [41-43], but also that of other cropping systems (arable crops, citrus and olive orchards, vineyards) in the Koiliaris CZO. The overgrazing of sites with natural vegetation [29] and their vulnerability to erosion, as they are located in higher elevation and are characterized by steep gradients [27], are considered responsible.

Differences in the respiration rate between crops disappeared when respiration rate was normalized against SOM content. These relationships, however, can be biased due to the variable contribution of autotrophic respiration or differences in environmental conditions. For instance, the greater canopy of avocado trees likely implies a greater root density and, hence, a larger contribution of autotrophic respiration compared to olive trees [44]. In addition, soils with higher SOM content may store more soil moisture which, in turn, can maintain higher respiration rates during the dry season. This hypothesis is supported by the seasonal pattern of the relationships between SOM and respiration (Figures 2 and 3).

Lab experiments to control for differences in autotrophic respiration between crops and environmental conditions revealed lower decomposition rates for the avocado litter and a higher proportion of recalcitrant compounds in the litter that likely corresponded to lignin (Figure 5). Overall, greater decomposition rates are indicative of better litter quality which favors SOM formation and its stability through the formation of associations with mineral surfaces [21]. However, the effect of litter quality on the formation of mineralassociated SOM is not always consistent [22]. For instance, accumulation of organic-C in mineral surfaces per unit of mineralized $C$ was lower in soils amended with highquality litters [19]. Litter with a high fraction of recalcitrant compounds may contribute to SOM accumulation directly by affecting litter turnover time or through interactions with environmental factors and microbial community composition [45-47]. The higher C:N ratio of avocado litter in the surface soil layer is indicative of less microbially-processed litter and provides support for a strong effect of litter chemistry on SOM accumulation. Differences in SOM persistence among sites have also been linked to litter composition, and these differences were mediated by gradients in environmental conditions and soil biogeochemistry supporting the role of litter chemistry as control of SOM sequestration [48].

Our findings also confirm a strong effect of soil properties on SOM [49,50]. Overall, SOM content increased with the clay and silt content, particularly at the upper soil layer[17,29,51], However, the lack of a significant relationship between clay content and SOC in fields planted with avocado indicates that additional factors mediated SOM stabilization and accumulation [52]. Such an influence was particularly evident in Sites 1 and 5 , which, although had a similar clay content, exhibited a remarkable difference in SOM content. The avocado field at Site 5 has been tilled annually during the last decade, which is expected to result in a significant depletion of SOM [53]; however, the SOM content was the highest, implying that SOM was strongly protected, likely through the formation of associations with the minerals. Considering the bulk chemistry of the soils, the only noted difference between them was the $\mathrm{CaO}$ content (Table 2). $\mathrm{Al}$ and Fe oxides dominate $\mathrm{SOM}$ stabilization in low $\mathrm{pH}$ soils in humid environments, but their contribution decreases with increasing $\mathrm{pH}$ [54]. Particularly in dry environments and soils with circum-neutral to alkaline $\mathrm{pH}$, as those in the Koiliaris CZO [32], divalent cations have a strong effect on SOM stabilization [55]. In dry climates, as with those in the Mediterranean region, calcium may stimulate SOM stabilization due to its higher availability [56] and greater ionic radius, which facilitates stronger binding energies through the formation of bridges 
with negatively charged moieties in organic molecules [50]. Divalent cations may also contribute to lignin protection [48].

Despite the common view for a low potential of Mediterranean soils to sequester C $[28,32,33,57,58]$, the findings of this study broaden the upper thresholds of SOC that can be reached at agroecosystems in the Mediterranean basin providing support that SOC contents can approach or even exceed the value of $7.5 \%$. If we assume a typical SOC content for agricultural fields in the Koiliaris CZO of approximately $2 \%$ (Figure 1), C accumulation rates from this baseline at the SOC levels measured in Sites 1 and 5 range between 1 to $1.8 \mathrm{t} \mathrm{C} /$ ha yr that are among the highest reported in the literature for the Mediterranean and the drylands [28,33,57,59-61]. Even though increases of SOC occur mainly in the surface soil, they may stimulate disproportionately positive impacts on the resilience of agroecosystems in the Mediterranean by alleviating the most important constraint of rain-fed agriculture and water availability, both through improvements on soil infiltration rates [62] as well as water holding capacity [63]. In addition, positive feedbacks are expected by maintaining, or even increasing, primary production of agroecosystems and, hence, litter inputs to the soil and SOM formation.

\section{Conclusions and Prospects}

The findings of our study enable us to make contributions on fundamental questions of land management in the Mediterranean agroecosystems, including achievable thresholds of SOC in soils $(\approx 8 \%)$, the effect of cropping systems (Olive vs Avocado trees), and the period required to reach this potential ( $<30$ years). Thus, the findings have profound implications for the design of soil conservation practices (e.g., selection and promotion of cropping systems, estimation of required organic amendments depending on crop type) compatible with Mediterranean conditions and developing initiatives that describe achievable targets of SOC restoration (2-7.5\%), depending on soil properties and depth and cropping systems. A more detailed understanding of the processes regulating the cycling of SOC in agroecosystems is, however, required particularly on the effects of litter amount and composition to translate them into successful agronomical practices with proved potential to improve soil health, which is the cornerstone of agricultural production. Furthermore, this information could also be used in model calibration for testing different scenarios of management to identify the best practices for the sustainable use of the soils in the long-term.

Supplementary Materials: The following are available online at https:/ /www.mdpi.com/article/10 .3390/su132313278/s1, Figure S1: Map of the sampling Sites (1 to 5) locations in the Koiliaris CZO, Figure S2: Relationships between clay (A) and clay plus silt content (B) and SOC for avocado and olive trees, Figure S3: Relationships between SOC and TN in the different sampling sites.

Author Contributions: N.V.P. conceptualized the study with contributions from G.G. and N.P.N.; N.V.P. and G.G. performed soil sampling and sample preparation; N.V.P. and V.A.T. designed and performed the laboratory experiments; D.M. performed mineralogical analysis; N.P.N. provided consumables and equipment; N.V.P. performed statistical analysis and wrote the manuscript with contributions from all authors. All authors have read and agreed to the published version of the manuscript.

Funding: This work was supported by resources of the Technical University of Crete and the RESCHEDULE Project funded by the Prima foundation.

Institutional Review Board Statement: Not applicable.

Informed Consent Statement: Not applicable.

Data Availability Statement: The data of the study are available upon request to the corresponding author.

Conflicts of Interest: The authors declare no conflict of interest. 


\section{References}

1. Haddix, M.L.; Paul, E.A.; Cotrufo, M.F. Dual, differential isotope labeling shows the preferential movement of labile plant constituents into mineral-bonded soil organic matter. Glob. Chang. Biol. 2016, 22, 2301-2312. [CrossRef]

2. Koide, R.T.; Nguyen, B.; Skinner, R.H.; Dell, C.J.; Peoples, M.S.; Adler, P.R.; Drohan, P.J. Biochar amendment of soil improves resilience to climate change. GCB Bioenergy 2014, 7, 1084-1091. [CrossRef]

3. de Andrade Bonetti, J.; Anghinoni, I.; de Moraes, M.T.; Fink, J.R. Resilience of soils with different texture, mineralogy and organic matter under long-term conservation systems. Soil Tillage Res. 2017, 174, 104-112. [CrossRef]

4. Lal, R. Soil carbon sequestration to mitigate climate change. Geoderma 2004, 123, 1-22. [CrossRef]

5. Kallenbach, C.M.; Frey, S.D.; Grandy, A.S. Direct evidence for microbial-derived soil organic matter formation and its ecophysiological controls. Nat. Commun. 2016, 7, 13630. [CrossRef]

6. Huang, W.; Hall, S.J. Elevated moisture stimulates carbon loss from mineral soils by releasing protected organic matter. Nat. Commun. 2017, 8, 1774. [CrossRef] [PubMed]

7. Keiluweit, M.; Wanzek, T.; Kleber, M.; Nico, P.; Fendorf, S. Anaerobic microsites have an unaccounted role in soil carbon stabilization. Nat. Commun. 2017, 8, 1771. [CrossRef]

8. Liang, C.; Schimel, J.P.; Jastrow, J. The importance of anabolism in microbial control over soil carbon storage. Nat. Microbiol. 2017, 2, 17105. [CrossRef] [PubMed]

9. Hemingway, J.D.; Rothman, D.H.; Grant, K.E.; Rosengard, S.Z.; Eglinton, T.I.; Derry, L.A.; Galy, V.V. Mineral protection regulates long-term global preservation of natural organic carbon. Nature 2019, 570, 228-231. [CrossRef]

10. Witzgall, K.; Vidal, A.; Schubert, D.I.; Höschen, C.; Schweizer, S.A.; Buegger, F.; Pouteau, V.; Chenu, C.; Mueller, C.W. Particulate organic matter as a functional soil component for persistent soil organic carbon. Nat. Commun. 2021, 12, 4115. [CrossRef]

11. Manzoni, S.; Schimel, J.P.; Porporato, A. Responses of soil microbial communities to water stress: Results from a meta-analysis. Ecology 2012, 93, 930-938. [CrossRef]

12. Machmuller, M.; Kramer, M.G.; Cyle, T.; Hill, N.; Hancock, D.; Thompson, A. Emerging land use practices rapidly increase soil organic matter. Nat. Commun. 2015, 6, 6995. [CrossRef]

13. Campo, J.; Merino, A. Variations in soil carbon sequestration and their determinants along a precipitation gradient in seasonally dry tropical forest ecosystems. Global Chang. Biol. 2016, 22, 1942-1956. [CrossRef] [PubMed]

14. Bradford, J.B.; Schlaepfer, D.R.; Lauenroth, W.K.; Yackulic, C.B.; Duniway, M.; Hall, S.; Jia, G.; Jamiyansharav, K.; Munson, S.M.; Wilson, S.D.; et al. Future soil moisture and temperature extremes imply expanding suitability for rainfed agriculture in temperate drylands. Sci. Rep. 2017, 7, 12923. [CrossRef] [PubMed]

15. Doetterl, S.; Berhe, A.A.; Arnold, C.; Bodé, S.; Fiener, P.; Finke, P.; Fuchslueger, L.; Griepentrog, M.; Harden, J.W.; Nadeu, E.; et al. Links among warming, carbon and microbial dynamics mediated by soil mineral weathering. Nat. Geosci. 2018, 11, 589-593. [CrossRef]

16. Barel, J.M.; Kuyper, T.W.; Paul, J.; De Boer, W.; Cornelissen, J.H.C.; De Deyn, G.B. Winter cover crop legacy effects on litter decomposition act through litter quality and microbial community changes. J. Appl. Ecol. 2019, 56, 132-143. [CrossRef]

17. Von Haden, A.C.; Kucharik, C.J.; Jackson, R.D.; Marín-Spiotta, E. Litter quantity, litter chemistry, and soil texture control changes in soil organic carbon fractions under bioenergy cropping systems of the North Central U.S. Biogeochemistry 2019, 143, 313-326. [CrossRef]

18. Manzoni, S. Flexible Carbon-Use Efficiency across Litter Types and during Decomposition Partly Compensates Nutrient Imbalances-Results from Analytical Stoichiometric Models. Front. Microbiol. 2017, 8, 661. [CrossRef]

19. Córdova, S.C.; Olk, D.C.; Dietzel, R.N.; Mueller, K.E.; Archontouilis, S.V.; Castellano, M.J. Plant litter quality affects the accumulation rate, composition, and stability of mineral-associated soil organic matter. Soil Biol. Biochem. 2018, 125, 115-124. [CrossRef]

20. Bai, Z.; Xie, H.; Kao-Kniffin, J.; Chen, B.; Shao, P.; Liang, C. Shifts in microbial trophic strategy explain different temperature sensitivity of $\mathrm{CO} 2$ flux under constant and diurnally varying temperature regimes. FEMS Microbiol. Ecol. 2017, 93. [CrossRef]

21. Cotrufo, M.F.; Wallenstein, M.D.; Boot, C.M.; Denef, K.; Paul, E. The Microbial Efficiency-Matrix Stabilization (MEMS) framework integrates plant litter decomposition with soil organic matter stabilization: Do labile plant inputs form stable soil organic matter? Glob. Chang. Biol. 2012, 19, 988-995. [CrossRef] [PubMed]

22. Castellano, M.J.; Mueller, K.; Olk, D.C.; Sawyer, J.E.; Six, J. Integrating plant litter quality, soil organic matter stabilization, and the carbon saturation concept. Glob. Chang. Biol. 2015, 21, 3200-3209. [CrossRef]

23. Cornwell, W.K.; Cornelissen, J.H.C.; Amatangelo, K.; Dorrepaal, E.; Eviner, V.; Godoy, O.; Hobbie, S.; Hoorens, B.; Kurokawa, H.; Pérez-Harguindeguy, N.; et al. Plant species traits are the predominant control on litter decomposition rates within biomes worldwide. Ecol. Lett. 2008, 11, 1065-1071. [CrossRef] [PubMed]

24. Wang, H.; Liu, S.-R.; Wang, J.-X.; Shi, Z.-M.; Xu, J.; Hong, P.-Z.; Ming, A.-G.; Yu, H.-L.; Chen, L.; Lu, L.-H.; et al. Differential effects of conifer and broadleaf litter inputs on soil organic carbon chemical composition through altered soil microbial community composition. Sci. Rep. 2016, 6, 27097. [CrossRef] [PubMed]

25. Tamura, M.; Suseela, V.; Simpson, M.; Powell, B.; Tharayil, N. Plant litter chemistry alters the content and composition of organic carbon associated with soil mineral and aggregate fractions in invaded ecosystems. Glob. Chang. Biol. 2017, 23, 4002-4018. [CrossRef]

26. Zhang, H.; Goll, D.S.; Manzoni, S.; Ciais, P.; Guenet, B.; Huang, Y. Modeling the effects of litter stoichiometry and soil mineral N availability on soil organic matter formation using CENTURY-CUE (v1.0). Geosci. Model Dev. 2018, 11, 4779-4796. [CrossRef] 
27. Tsiknia, M.; Paranychianakis, N.V.; Varouchakis, E.A.; Moraetis, D.; Nikolaidis, N. Environmental drivers of soil microbial community distribution at the Koiliaris Critical Zone Observatory. FEMS Microbiol. Ecol. 2014, 90, 139-152. [CrossRef] [PubMed]

28. Apostolakis, A.; Panakoulia, S.; Nikolaidis, N.; Paranychianakis, N.V. Shifts in soil structure and soil organic matter in a chronosequence of set-aside fields. Soil Tillage Res. 2017, 174, 113-119. [CrossRef]

29. Moraetis, D.; Paranychianakis, N.; Nikolaidis, N.; Banwart, S.; Rousseva, S.; Kercheva, M.; Nenov, M.; Shishkov, T.; De Ruiter, P.; Bloem, J.; et al. Sediment provenance, soil development, and carbon content in fluvial and manmade terraces at Koiliaris River Critical Zone Observatory. J. Soils Sediments 2015, 15, 347-364. [CrossRef]

30. Bouyoucos, G.J. Hydrometer Method Improved for Making Particle Size Analyses of Soils 1. Agron. J. 1962, 54, 464-465. [CrossRef]

31. Keuskamp, J.A.; Dingemans, B.J.J.; Lehtinen, T.; Sarneel, J.; Hefting, M. Tea Bag Index: A novel approach to collect uniform decomposition data across ecosystems. Methods Ecol. Evol. 2013, 4, 1070-1075. [CrossRef]

32. Tsiknia, M.; Paranychianakis, N.V.; Varouchakis, E.A.; Nikolaidis, N. Environmental drivers of the distribution of nitrogen functional genes at a watershed scale. FEMS Microbiol. Ecol. 2015, 91, fiv052. [CrossRef] [PubMed]

33. Nieto, O.M.; Castro-Rodriguez, J.; Fernández, E.; Smith, P. Simulation of soil organic carbon stocks in a Mediterranean olive grove under different soil-management systems using the RothC model. Soil Use Manag. 2010, 26, 118-125. [CrossRef]

34. Aguilera, E.; Guzmán, G.I.; Álvaro-Fuentes, J.; Infante-Amate, J.; García-Ruiz, R.; Carranza-Gallego, G.; Soto, D.; de Molina, M.G. A historical perspective on soil organic carbon in Mediterranean cropland (Spain, 1900-2008). Sci. Total Environ. 2018, 621, 634-648. [CrossRef]

35. Rinot, O.; Levy, G.J.; Steinberger, Y.; Svoray, T.; Eshel, G. Soil health assessment: A critical review of current methodologies and a proposed new approach. Sci. Total Environ. 2019, 648, 1484-1491. [CrossRef]

36. Álvaro-Fuentes, J.; Paustian, K. Potential soil carbon sequestration in a semiarid Mediterranean agroecosystem under climate change: Quantifying management and climate effects. Plant Soil 2011, 338, 261-272. [CrossRef]

37. Harden, J.W.; Hugelius, G.; Ahlström, A.; Blankinship, J.C.; Bond-Lamberty, B.; Lawrence, C.R.; Loisel, J.; Malhotra, A.; Jackson, R.B.; Ogle, S.; et al. Networking our science to characterize the state, vulnerabilities, and management opportunities of soil organic matter. Global Chang. Biol. 2018, 24, e705-e718. [CrossRef] [PubMed]

38. Giannakis, G.; Panakoulia, S.; Nikolaidis, N.; Paranychianakis, N. Simulating Soil Fertility Restoration Using the CAST Model. Procedia Earth Planet. Sci. 2014, 10, 325-329. [CrossRef]

39. Murovhi, N.R.; Materechera, S.A.; Mulugeta, S.D. Seasonal changes in litter fall and its quality from three sub-tropical fruit tree species at Nelspruit, South Africa. Agrofor. Syst. 2012, 86, 61-71. [CrossRef]

40. Suseela, V.; Tharayil, N. Decoupling the direct and indirect effects of climate on plant litter decomposition: Accounting for stress-induced modifications in plant chemistry. Global Chang. Biol. 2018, 24, 1428-1451. [CrossRef]

41. Kurganova, I.; De Gerenyu, V.L.; Six, J.; Kuzyakov, Y. Carbon cost of collective farming collapse in Russia. Global Chang. Biol. 2013, 20, 938-947. [CrossRef]

42. Akpa, S.I.; Odeh, I.O.; Bishop, T.F.; Hartemink, A.E.; Amapu, I.Y. Total soil organic carbon and carbon sequestration potential in Nigeria. Geoderma 2016, 271, 202-215. [CrossRef]

43. Barré, P.; Angers, D.A.; Basile-Doelsch, I.; Bispo, A.; Cécillon, L.; Chenu, C.; Chevallier, T.; Derrien, D.; Eglin, T.K.; Pellerin, S. Ideas and perspectives: Can we use the soil carbon saturation deficit to quantitatively assess the soil carbon storage potential, or should we explore other strategies? Biogeosci. Discuss. 2017, 1-12. [CrossRef]

44. Lee, J.-S. Relationship of root biomass and soil respiration in a stand of deciduous broadleaved trees-A case study in a maple tree. J. Ecol. Environ. 2018, 42, 19. [CrossRef]

45. Boerjan, W.; Ralph, J.; Baucher, M. Lignin Biosynthesis. Annu. Rev. Plant Biol. 2003, 54, 519-546. [CrossRef]

46. Forney, D.C.; Rothman, D.H. Common structure in the heterogeneity of plant-matter decay. J. Royal Soc. Interface 2012, 9, 2255-2267. [CrossRef]

47. Zakem, E.J.; Cael, B.B.; Levine, N.M. A unified theory for organic matter accumulation. Proc. Natl. Acad. Sci. USA 2021, 118, 2016896118. [CrossRef]

48. Hall, S.J.; Ye, C.; Weintraub, S.R.; Hockaday, W.C. Molecular trade-offs in soil organic carbon composition at continental scale. Nat. Geosci. 2020, 13, 687-692. [CrossRef]

49. Oades, J.M. The retention of organic matter in soils. Biogeochemistry 1988, 5, 35-70. [CrossRef]

50. Mikutta, R.; Kleber, M.; Torn, M.; Jahn, R. Stabilization of Soil Organic Matter: Association with Minerals or Chemical Recalcitrance? Biogeochemistry 2006, 77, 25-56. [CrossRef]

51. Torres-Sallan, G.; Schulte, R.; Lanigan, G.J.; Byrne, K.A.; Reidy, B.; Simó, I.; Six, J.; Creamer, R.E. Clay illuviation provides a long-term sink for C sequestration in subsoils. Sci. Rep. 2017, 7, 45635. [CrossRef] [PubMed]

52. Rasmussen, C.; Heckman, K.; Wieder, W.R.; Keiluweit, M.; Lawrence, C.R.; Berhe, A.A.; Blankinship, J.C.; Crow, S.E.; Druhan, J.L.; Hicks Pries, C.E.; et al. Beyond clay: Towards an improved set of variables for predicting soil organic matter content. Biogeochemistry 2018, 137, 297-306. [CrossRef]

53. Haddaway, N.R.; Hedlund, K.; Jackson, L.E.; Kätterer, T.; Lugato, E.; Thomsen, I.K.; Jørgensen, H.B.; Isberg, P.-E. How does tillage intensity affect soil organic carbon? A systematic review. Environ. Rev. 2017, 6, 30. [CrossRef]

54. Rowley, M.C.; Grand, S.; Verrecchia, É.P. Calcium-mediated stabilisation of soil organic carbon. Biogeochemistry 2018, 137, 27-49. [CrossRef] 
55. Lutzow, M.V.; Kögel-Knabner, I.; Ekschmitt, K.; Matzner, E.; Guggenberger, G.; Marschner, B.; Flessa, H. Stabilization of organic matter in temperate soils: Mechanisms and their relevance under different soil conditions-A review. Eur. J. Soil Sci. 2006, 57, 426-445. [CrossRef]

56. Smith, D.; Cannon, W.F.; Woodruff, L.G.; Solano, F.; Ellefsen, K.J. Geochemical and Mineralogical Maps for Soils of the Conter-Minous United States; US Geological Survey: Reston, VA, USA, 2014; p. 399.

57. Álvaro-Fuentes, J.; Easter, M.; Paustian, K. Climate change effects on organic carbon storage in agricultural soils of northeastern Spain. Agric. Ecosyst. Environ. 2012, 155, 87-94. [CrossRef]

58. Nieto, O.M.; Castro, J.; Fernández-Ondoño, E. Conventional tillage versus cover crops in relation to carbon fixation in Mediterranean olive cultivation. Plant Soil 2013, 365, 321-335. [CrossRef]

59. Vicente-Vicente, J.L.; García-Ruiz, R.; Francaviglia, R.; Aguilera, E.; Smith, P. Soil carbon sequestration rates under Mediterranean woody crops using recommended management practices: A meta-analysis. Agric. Ecosyst. Environ. 2016, 235, 204-214. [CrossRef]

60. Novara, A.; Gristina, L.; Sala, G.; Galati, A.; Crescimanno, M.; Cerdà, A.; Badalamenti, E.; La Mantia, T. Agricultural land abandonment in Mediterranean environment provides ecosystem services via soil carbon sequestration. Sci. Total Environ. 2017, 576, 420-429. [CrossRef]

61. Bell, S.M.; Terrer, C.; Barriocanal, C.; Jackson, R.B.; Rosell-Melé, A. Soil organic carbon accumulation rates on Mediterranean abandoned agricultural lands. Sci. Total Environ. 2021, 759, 143535. [CrossRef]

62. Basche, A.D.; DeLonge, M.S. Comparing infiltration rates in soils managed with conventional and alternative farming methods: A meta-analysis. PLoS ONE 2019, 14, e0215702. [CrossRef] [PubMed]

63. Nichols, R. A Hedge against Drought: Why Healthy Soil Is 'Water in the Bank'; United States Department of Agriculture, Natural Resources Conservation Service. 2015. Available online: https://www.usda.gov/media/blog/2015/05/12/hedge-againstdrought-why-healthy-soil-water-bank (accessed on 28 November 2021). 